\title{
Evaluating economic and environmental aspects of using solar panels on multi-angled facades of office buildings
}

\author{
Hannoudi, Loay Akram; Lauring, Michael; Christensen, Jørgen Erik
}

Published in:

AIP Conference Proceedings

Link to article, DOI:

$10.1063 / 1.5002510$

Publication date:

2017

Document Version

Publisher's PDF, also known as Version of record

Link back to DTU Orbit

Citation (APA):

Hannoudi, L. A., Lauring, M., \& Christensen, J. E. (2017). Evaluating economic and environmental aspects of using solar panels on multi-angled facades of office buildings. AlP Conference Proceedings, 1884, [020006]. https://doi.org/10.1063/1.5002510

\section{General rights}

Copyright and moral rights for the publications made accessible in the public portal are retained by the authors and/or other copyright owners and it is a condition of accessing publications that users recognise and abide by the legal requirements associated with these rights.

- Users may download and print one copy of any publication from the public portal for the purpose of private study or research.

- You may not further distribute the material or use it for any profit-making activity or commercial gain

- You may freely distribute the URL identifying the publication in the public portal 


\section{Evaluating economic and environmental aspects of using solar panels on multi-angled facades of office buildings}

Loay Akram Hannoudi, Michael Lauring, and Jørgen Erik Christensen

Citation: AIP Conference Proceedings 1884, 020006 (2017); doi: 10.1063/1.5002510

View online: http://dx.doi.org/10.1063/1.5002510

View Table of Contents: http://aip.scitation.org/toc/apc/1884/1

Published by the American Institute of Physics

\section{Articles you may be interested in}

A novel load balanced energy conservation approach in WSN using biogeography based optimization AIP Conference Proceedings 1884, 020003 (2017); 10.1063/1.5002507

Humid free efficient solar panel

AIP Conference Proceedings 1884, 020002 (2017); 10.1063/1.5002506

Property analysis into the formation of liquid falling thin film on a single channel of a vertical twisted and fluted tube

AIP Conference Proceedings 1884, 020004 (2017); 10.1063/1.5002508

Optimal design of high concentration reflected photovoltaic module

AIP Conference Proceedings 1884, 020001 (2017); 10.1063/1.5002505

Relation between plastic surface microtexturation and $\mathrm{Ag}$ film percolation and resistivity

AIP Conference Proceedings 1884, 030001 (2017); 10.1063/1.5002511

Analysis of seasonal exergy efficiency of an air handling unit

AIP Conference Proceedings 1884, 020005 (2017); 10.1063/1.5002509 


\title{
Evaluating Economic and Environmental Aspects of Using Solar Panels on Multi-Angled Facades of Office Buildings
}

\author{
Loay Akram Hannoudi, ${ }^{1, \text { a) }}$ Michael Lauring ${ }^{2, \text { b) }}$ and Jørgen Erik Christensen ${ }^{3, c)}$ \\ ${ }^{I}$ PhD student, Department of Architecture, Design and Media Technology, Aalborg University, Rendsburggade $14 \mid$ \\ 9000 Aalborg, Denmark \\ ${ }^{2}$ Associate professor, Department of Architecture, Design and Media Technology, Aalborg University, \\ Rendsburggade 14 | 9000 Aalborg.Denmark \\ ${ }^{3}$ Associate Professor, Department of Civil Engineering, Denmark Technical University, Brovej - Building 118, 2800 \\ Lyngby, Denmark \\ a) lah@create.aau.dk, \\ b) mlau@create.aau.dk, \\ c) jec@byg.dtu.dk
}

\begin{abstract}
This paper is concerned with using solar panels as high-tech cladding materials on multi-angled facades for office buildings. The energy produced by the solar panels will be consumed inside the office rooms by cooling compressors, ventilation, lighting and office equipment. Each multi-angled facade unit is directed into two different orientations on a vertical axis (right and left), but not tilted up and down. The different facade orientations will optimize the use of solar radiation to produce the needed energy from the solar panels when placing them on the parapets of these facades. In this regard, four scenarios with different facade configurations and orientations are evaluated and discussed. The method for the simulations and calculations depends on two main programs: first, IDA ICE program to calculate the energy consumption and evaluate the indoor climate of the building; and second, PVBAT to calculate the cost of the electricity produced by the solar panels and evaluate the total amount of energy produced from these panels along with the ratio to the energy bought directly from the electricity grid. There is also an environmental evaluation for the system by calculating the $\mathrm{CO}_{2}$ emissions in the different scenarios.
\end{abstract}

\section{INTRODUCTION}

A Multi-angled Façade System is the result of an interdisciplinary study proposing the use of two or more different orientations of windows in each façade to optimize the use of solar radiation and daylight through the façades, depending on the appropriate window properties and the solar shading control system [1]. This research focuses on using solar panels as high-tech cladding materials on this facade system to utilize the potentials of the different facade orientations. The power incident on a PV module depends not only on the power contained in the sunlight, but also on the angle between the module and the sun [2]. This leads to a need to position the solar panels on the parapets of these facades in order to optimize the use of solar radiation to produce the energy required. The environmental impact of electricity generation, particularly the greenhouse effect, adds an important reason for examining solar panels [2]. Using solar panels helps to reduce $\mathrm{CO}_{2}$ emissions compared to fossil energy sources, which is evaluated in this research. This research reveals a new potential of the Multi-angled Façade Systems and differs from prior research by focusing on the way of dealing with and evaluating the use of solar panels.

\section{METHOD}

- The first step uses the IDA ICE program [3], which is a simulation application for the accurate study of the indoor climate of individual thermal zones in a building and energy consumption for the entire building. The 
program is made by EQUA, a privately held Swedish company, dedicated to developing state of the art simulation tools.

- The second step makes use of PVBAT [4], which is an Excel-based program developed by Danish companies such as COWI [5]. The program is used to calculate the cost of electricity that is produced by the solar panels and to evaluate the amount and percentage of energy produced from these panels compared to energy bought directly from the electricity grid. The program is also used to calculate the $\mathrm{CO} 2$ emissions in different scenarios.

\section{INPUT DATA TO THE SIMULATIONS}

\section{The Simulation in IDA ICE}

Scenario 1:

- According to the analyses made for different buildings in Copenhagen [6], three adjacent rooms with inner dimensions $5 \mathrm{~m} \times 4.5 \mathrm{~m} \times 3 \mathrm{~m}(\mathrm{~L} \times \mathrm{W} \times \mathrm{H})$ are chosen for the simulation in IDA ICE. The rooms each have one external façade oriented to the west and adjacent rooms above, below and on each side.

- Two occupants are working in each room (occupancy 80\%) [7], with two computers (40 W/pc).

- Electrical lighting is in use during the occupancy hours and is assumed to be energy efficient lighting that provides 500 Lux for the working area of the office room [7] (which is assumed to be $2 / 3$ of the room area). The electrical lighting has a total lighting power of $110 \mathrm{~W}$ with luminous efficacy of $80 \mathrm{~lm} / \mathrm{W}$. An energy efficient fluorescent lighting is used for electrical lighting.

- The mechanical ventilation system is VAV during working hours (08:00-17:00). The control depends on room temperature and $\mathrm{CO}_{2}$ concentration. The heat exchanger efficiency is $80 \%$.

- A cooling compressor is used during working hours between May and September. The COP is 3.

- The air change through leaks in the building envelope does not exceed $0.5 \mathrm{l} / \mathrm{s} \mathrm{per} \mathrm{m}^{2}$ floor area by pressure test with $50 \mathrm{~Pa}$, as suggested by a report from "Erhvervs- og Byggestyrelsen" for building class 2020 [8].

- The chosen window for the renovation is a three-layer glass window $\left(\mathrm{U}_{\mathrm{g}}\right.$ is $0.51 \mathrm{~W} / \mathrm{m}^{2} \mathrm{~K}, \mathrm{LT}_{\mathrm{g}} 0.71, \mathrm{~g}_{\mathrm{g}} 0.5, \mathrm{U}_{\mathrm{f}}$ $1.56 \mathrm{~W} / \mathrm{m}^{2} \mathrm{~K}$ )[9]. The U-value of the external wall is $0.125 \mathrm{~W} / \mathrm{m}^{2} \mathrm{~K}$, which is lower than the maximum value of $0.18 \mathrm{~W} / \mathrm{m}^{2} \mathrm{~K}$ specified in BR15 [10]. The shading device is external, with shading coefficient 0.14 . The shading system depends on solar radiation intensity (closes at $125 \mathrm{~W} / \mathrm{m}^{2}$ (solar radiation intensity measured internally)).
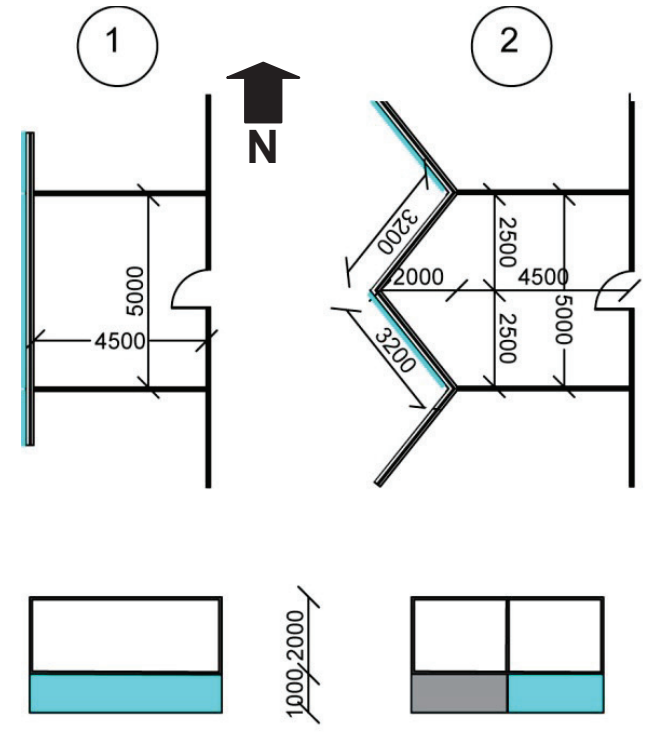

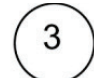

$\underline{\text { Plans }}$
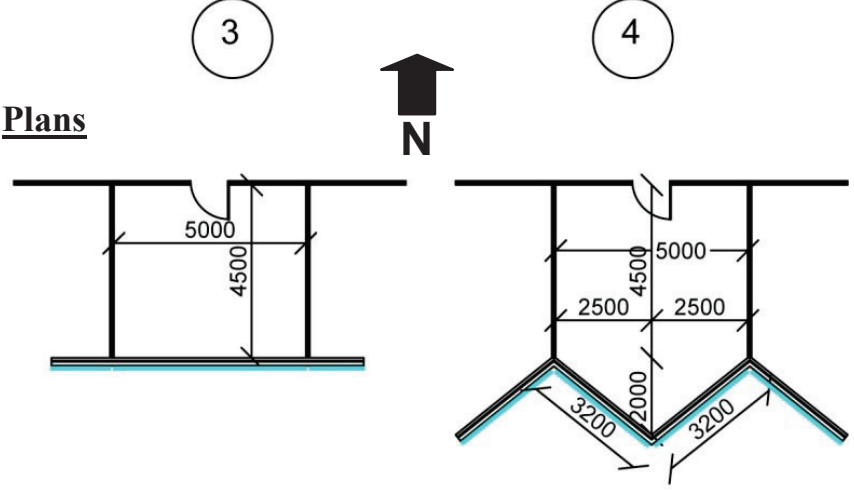

Front facades

The proposed placement of solar panels
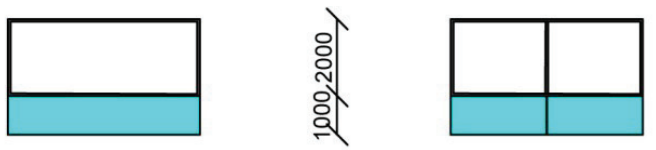

FIGURE 1. The office room configuration and orientation in the scenarios: $1,2,3$ and 4 with a proposed placement of PV panels 
Scenario 2:

Three office rooms with multi-angled façades oriented to the west. The same input data as in scenario 1 regarding lighting, cooling system, heating, internal gain, shading system and ventilation system are used. The properties of the windows are: $\left(\mathrm{U}_{\mathrm{g}}\left(\mathrm{W} / \mathrm{m}^{2} \mathrm{~K}\right), \mathrm{g}_{\mathrm{g}}(\%), \mathrm{Lt}_{\mathrm{g}}(\%)\right)(0.51,0.5,0.71)[9]$.

Scenario 3:

Three adjacent office rooms with flat facade oriented toward south. The same input data as in scenario 1 are used except for the difference in the orientation.

Scenario 4:

Three office rooms with multi-angled façades oriented to the south. For the windows towards southwest and southeast: $\left(\mathrm{U}_{\mathrm{g}}\left(\mathrm{W} / \mathrm{m}^{2} \mathrm{~K}\right), \mathrm{g}_{\mathrm{g}}(\%), \mathrm{Lt}_{\mathrm{g}}(\%)(0.51,0.5,0.71)\right)[9]$. The remaining input data (lighting, cooling system, heating, internal gain, shading system and ventilation system) are the same as in scenario 1.

The area of the parapet for proposed placement of solar panels per one office room is $\left(5 \mathrm{~m}^{2}\right)$ in scenario1, $(2.22$ $\left.\mathrm{m}^{2}\right)$ in scenario2, $\left(5 \mathrm{~m}^{2}\right)$ in scenario3 and $\left(6.4 \mathrm{~m}^{2}\right)$ in scenario4.

The simulation in IDA ICE is a whole-year detailed and dynamic multi-zone simulation application for study of thermal indoor climate as well as the energy consumption of the entire building.

\section{The Simulation in PVBAT}

In general, the solar system consists of five main parts: The solar panels to produce energy, the battery to save energy when it is not used, the inverter to change the current from $\mathrm{DC}$ to $\mathrm{AC}$, the equipment to consume the energy and the electricity grid to sell the surplus energy. The program PVBAT can analyze the input data from these five parts and provide economic, environmental and energy efficient solutions for the whole system including a large number of parameter variations.

The input data for the solar system are:

- Monocrystalline solar panels with a production peak of $170 \mathrm{~W} / \mathrm{m}^{2}$ and a price of $11000 \mathrm{kr} / \mathrm{kW}[11]$.

- The area of the solar panels is given as a percentage of the parapet area in the results.

- The battery has a nominal capacity of $0.5 \mathrm{kWh}$ and the price is $2500 \mathrm{kr} . / \mathrm{kWh}$ of the nominal capacity (including the inverter).

- The lifetime of the system is 30 years.

- The average electricity price for buying is $2.275 \mathrm{kr} . / \mathrm{kWh}$ and the average electricity price for selling is 0.6 $\mathrm{kr} . / \mathrm{kWh}[4]$.

- $\mathrm{CO}_{2}$ emission is $224 \mathrm{~g} / \mathrm{kWh}[12]$.

- The energy that is produced by the solar panels and consumed is determined by the results of the simulations in the program IDA ICE.

There are two positions of the solar panels: vertically fixed on the parapet, and tilted at $60^{\circ}$. The parapets are partially covered with solar panels, and the percentage coverage depends on energy consumption requirements. The percentage coverage is optimized as shown in the results.

\section{RESULTS}

\section{Results of Simulation in IDA ICE}

In the different scenarios, energy is consumed by cooling compressors, ventilation (fan \& pump), lighting and equipment such as computers. Heating is provided in the form of district heating. The energy consumption is calculated as an hourly profile ( 8760 hours). It is assumed that the energy consumption is the same for scenarios 1 and 2 in order to make a comparison between the designs of the solar systems for each. The same approach is taken regarding energy consumption in scenarios 3 and 4.

- The energy consumption in scenarios 1 and 2 is $1030 \mathrm{kWh} /$ year.

- The energy consumption in scenarios 3 and 4 is $1095 \mathrm{kWh} /$ year.

The number of overheating hours that exceed $26^{\circ} \mathrm{C}$ for the four scenarios varies between 1 to 6 hours per a year. The number of overheating hours that exceed $27^{\circ} \mathrm{C}$ is 0 hours per year. The low number of overheating hours is because of using cooling compressor for cooling the office rooms during working hours. 


\section{Results of the Simulation in PVBAT}

TABLE 1: Results of Simulations in PVBAT for the different scenarios: $1,2,3$ and 4

\begin{tabular}{|c|c|c|c|c|}
\hline & $\begin{array}{c}\text { Scenario } 1 \\
\text { Vertical } 90^{\circ} \\
\text { Tilted } 60^{\circ}\end{array}$ & $\begin{array}{c}\text { Scenario } 2 \\
\text { Vertical } 90^{\circ} \\
\text { Tilted } 60^{\circ}\end{array}$ & $\begin{array}{c}\text { Scenario } 3 \\
\text { Vertical } 90^{\circ} \\
\text { Tilted } 60^{\circ}\end{array}$ & $\begin{array}{c}\text { Scenario } 4 \\
\text { Vertical } 90^{\circ} \\
\text { Tilted } 60^{\circ}\end{array}$ \\
\hline $\mathrm{PV}$ area to parapet area $\%$ & $60 \% / 60 \%$ & $70 \% / 70 \%$ & $40 \% / 40 \%$ & $40 \% / 40 \%$ \\
\hline $\mathrm{PV}$ production $\mathrm{kWh} /$ year & $747 / 969$ & $772 / 1001$ & $659 / 867$ & $890 / 1151$ \\
\hline $\begin{array}{l}\text { PV production to direct usage } \\
\mathrm{kWh} / \text { year }\end{array}$ & $334 / 427$ & $369 / 458$ & $379 / 467$ & $451 / 543$ \\
\hline $\begin{array}{l}\text { Electric consumption direct } \\
\text { from the net } \mathrm{kWh} / \text { year }\end{array}$ & $639 / 545$ & $599 / 510$ & $663 / 572$ & 584 / 494 \\
\hline $\begin{array}{l}\text { Electricity sold to the net } \\
\mathrm{kWh} / \text { year }\end{array}$ & $346 / 474$ & $331 / 470$ & $222 / 339$ & $374 / 544$ \\
\hline $\begin{array}{l}\text { Covering own consumption } \\
\text { from PV } \%\end{array}$ & $39 \% / 48 \%$ & $43 \% / 51 \%$ & $40 \% / 48 \%$ & $47 \% / 55 \%$ \\
\hline $\mathrm{CO} 2$ emission tone/year & $0.143 / 0.122$ & $0.134 / 0.114$ & $0.148 / 0.128$ & $0.130 / 0.110$ \\
\hline $\begin{array}{l}\text { Price per kWh delivered } \\
\mathrm{kr} / \mathrm{kWh}\end{array}$ & $3.23 / 2.95$ & $2.84 / 2.56$ & $2.59 / 2.34$ & $2.83 / 2.55$ \\
\hline
\end{tabular}

\section{DISCUSSION}

The power incident on a PV module depends not only on the power contained in the sunlight, but also on the angle between the module and the sun. In this regard, two angles are important: the angle between the solar radiation and a line perpendicular to the PV surface through a vertical plane, which can be optimized by tilting the PV panels. The second angle is the azimuth angle which the PV module faces, which can be optimized by turning the PV panels to a different orientation.

Multi-angled facades provide two orientations on each room facade that can optimize the amount of solar radiation absorbed by PV panels through, on the one hand, an improved azimuth angle of orientation of the PV module in relation to the azimuth angle of the sun; and, on the other hand, increasing the area of the parapet to accommodate larger PV panels. Using solar panels as a high-tech cladding material can save the cost of using normal cladding material in addition to producing energy and giving a unique expression to the facade. In general, the energy produced from solar panels on the roof might be higher due to better inclination of the panels, while a multi-angled facade can provide a better orientation of the solar panels. Using solar panels on multi-angled facades is evaluated through four scenarios using the program PVBAT. The four scenarios are for office rooms oriented to the west and south, with either a flat or multi-angled facade. The area of the parapet that is covered with solar panels is optimized according to the energy consumption. The price of the energy produced by solar panels in $\mathrm{kr} . / \mathrm{kWh}$ is also considered, because larger solar panels imply a higher price for the energy produced.

Scenarios 1 and 2 represent a flat facade and a multi-angled facade, respectively, oriented to the west. The area of solar panels is higher in scenario 1 by $28 \%$ compared to scenario 2 . The energy produced per square meter of solar panels is higher in scenario 2 compared to scenario $1\left(115 \mathrm{kWh} / \mathrm{m}^{2}\right.$ in scenario 2 and $83 \mathrm{kWh} / \mathrm{m}^{2}$ in scenario 1$)$. This is because of the better orientation in scenario 2 . The values concerning the energy produced from solar panels and internal consumption from solar panels, as percentages, are higher in scenario 2 compared to scenario 1, which is a positive aspect. The directly used, the electricity consumption direct from the grid is higher in scenario 1, which is also a positive aspect for scenario 2 . However, since the area of solar panels is smaller in scenario 2, this leads to a lower price per $\mathrm{kWh}$ in scenario 2 compared to scenario $1(3.23 \mathrm{kr} . / \mathrm{kWh}$ in scenario 1 and $2.84 \mathrm{kr} . / \mathrm{kWh}$ in scenario 2 ). The electricity sold to the net is a little higher in scenario 1 compared to scenario 2 . However, this did not have a large impact on the price of the energy produced from solar panels because of the low price of the energy sold to the grid. The $\mathrm{CO}_{2}$ emissions in scenarios 1 are higher than in scenario $2(0.143$ tonne/year in scenario 1 and 0.134 tonne/year in scenario 2). This is because the electricity purchased from the grid is more in scenario 1. 
Scenarios 3 and 4 represent a flat facade and a multi-angled facade oriented to the south. The parapet area in scenario 4 is larger by $28 \%$ compared to the area in scenario 3 . The ratio of solar panel area to parapet area is the same in the two scenarios. The energy produced by solar panels in scenario 4 is larger by $35 \%$ compared to the energy produced in scenario 3. Coverage of the building's internal consumption from solar panels is better in scenario 4 compared to scenario 3 (47\% in scenario 4 and $40 \%$ in scenario 3 ). Electricity used directly from the grid is lower in scenario 4 by $12 \%$ compared to scenario 3 , and this has a positive impact on the final price for electricity. However, the price of electricity produced in scenario 3 is still lower than in scenario $4(2.59 \mathrm{kr} . / \mathrm{kWh}$ in scenario 3 and $2,83 \mathrm{kr} . / \mathrm{kWh}$ in scenario 4). This is because the area of solar panels is larger in scenario 4 compared to scenario 3 , therefore the cost is higher. Furthermore, the electricity sold to the net is greater in scenario 4 by $68 \%$ compared to scenario 3, where the price of electricity sold is low. This means also that there is more surplus energy in scenario 4 that can be consumed in other building parts oriented to the north, where there are no solar panels on the facade. If a use for this energy surplus is found, the final price of electricity might become lower than in scenario 3.

Changing the facade orientation from south towards east or west will increase the potential of a multi-angled facade to optimize the orientation of solar panels. Changing the orientation towards the north will stop this potential.

Tilting the solar panels has a positive impact on the energy produced and $\mathrm{CO}_{2}$ emissions. Tilting the solar panels by $60^{\circ}$ increased the energy produced by $30 \%$ in scenario $1,30 \%$ in scenario $2,32 \%$ in scenario 3 and $29 \%$ in scenario 4 compared to vertical solar panels. $\mathrm{CO}_{2}$ emissions are also reduced by tilting the solar panels by $60^{\circ}: 15 \%$ in scenario $1,15 \%$ in scenario $2,14 \%$ in scenario 3 and $15 \%$ in scenario 4 , compared to vertical solar panels. Having the solar panels tilted on the facade will change their function as a cladding material. Tilting the solar panels has an impact on the aesthetic element of the facade and might change the expression of it. This will give rise to a discussion about having the solar panels tilted, but this will not be discussed in this research paper.

\section{CONCLUSION}

The results of the simulations in PVBAT show that the different orientations in the multi-angled facades have the potential to be utilized for the installation of solar panels. This is due to the differences in the results for the energy produced and, to some degree, the energy price, when making comparisons between scenarios 1 and 2 and also between scenarios 3 and 4 . Scenario 2 showed greater potential for placing solar panels on the facade compared to scenario 1 due to better orientation, while scenario 4 provided a larger area for placing solar panels, culminating in much more energy produced. The ratio of the solar panel area to the parapet area can be increased to produce more energy for consumption in other parts in the building. The low price of the energy sold to the net has a negative impact on the final energy price and it is better to consume as much as possible of the energy produced from the

solar panels. Environmentally, using solar panels helps to reduce $\mathrm{CO}_{2}$ emissions compared to other energy sources such as fossil fuels, and $\mathrm{CO}_{2}$ emissions are much lower when using multi-angled facades.

\section{REFERENCES}

1. L. A Hannoudi, "Multi-angled facade system for office building renovation," in Advanced Building Skins2016, Conference Proceedings.

2. C. Honsberg and S. Bowden. PV EDUCATION ORG. [Online] Jan. 2017, http://www.pveducation.org.

3. IDA indoor climate and energy, "IDA ICE version 4.7.1", Stockholm, 2017.

4. COWI A/S, "PVBAT," Lyngby, 30 November 2016.

5. COWI A/S. [Online] April 2017, http://www.cowi.dk

6. L. Kalkerup\& B. Kaplan, "Facade systems for existing office buildings in Copenhagen," Master's thesis, DTU, 2014.

7. Technical Committee CEN/TC 156, "prEN 15251 Indoor environmental input parameters for design and assessment of energy performance of buildings," European Commission, 2006.

8. Enterprise and Construction Authority "Erhvervs- og Byggestyrelsen. Background report about building class 202," Energy Agency, Copenhagen, 2011.

9. Secretariat of the energy labeling scheme for vertical windows, "Energy windows," [Online] 2016. http://energivinduer.dk.

10. Building and housing agency, "Building regulation 2015," Energy Agency, Copenhagen, 2015.

11. Viasol, "Solar systems" (private communication) April 2017.

12. DONG Energy A/S. [Online] April 2017, https://www.dongenergy.dk. 